\title{
Evaluating the Competitive Ability of Semi-Leafless Field Pea Cultivars
}

\author{
$\begin{array}{llllll}1 & 1 & 2 & 1 & 1\end{array}$ \\ C.E. Jacob , M.E. Lawless , M. Dyck , S.J Shirtliffe , T.D. Warkentin , C.J Willenborg \\ 1 \\ Department of Plant Sciences, University of Saskatchewan, Saskatoon, SK \\ Department of Renewable Resources, University of Alberta, Edmonton, AB
}

Key Words: competitive ability, competition, tolerance, weed suppression, crop variety, crop genotypes, pulse crops, integrated weed management, field pea.

\begin{abstract}
Field pea (Pisum sativum L.) is an important grain legume in Western Canada. Growers can, however, be reluctant to include pulse crops in their rotation because they are poor competitors with weeds. Developing more competitive field pea cultivars is important to mitigate weed competition. The identification of competitive cultivars and the traits conferring competitive ability should lead to the development of more competitive field pea cultivars. The objective of this research was to evaluate the ability of semi-leafless field pea cultivars to suppress and withstand weed competition and to identify traits that may confer competitive ability in field pea. Field experiments were conducted in 2012 and 2013 at Floral, Saskatchewan, Saskatoon, Saskatchewan and St. Albert, Alberta. Fourteen semi-leafless field pea cultivars were seeded at a target density of 75 plants $\mathrm{m}^{-2}$ under weedy and weed-free conditions. Imidazolinonetolerant wheat (c.v. CDC Imagine) and canola (c.v. 45H73) were planted as pseudo weeds in the weedy plots. There was no cultivar by treatment interaction for all of the measured variables thus, cultivars did not differ in the presence or absence of weed competition. CDC Dakota produced the greatest pea yield and Reward produced the poorest pea yield at Saskatchewan. CDC Dakota and CDC Striker were among the best for pea biomass production at Saskatchewan, compared to Reward, which was among the worst. CDC Centennial and CDC Mozart were significantly better at Saskatchewan for their ability to withstand competition, while CDC Dakota, CDC Patrick, and CDC Meadow were statistically the best in their ability to compete with the pseudo weeds. At Alberta, CDC Striker and CDC Dakota were statistically best in their ability to compete with the pseudo weeds, versus Cooper and Stratus, who were among the poorest. At both Saskatchewan and Alberta, no correlations were strong enough to show which traits are conferring competitiveness in semi-leafless field pea cultivars.
\end{abstract}

\section{Introduction}

Field peas are vulnerable to many pests including weeds. Weed competition can be detrimental to field pea yields as weeds compete vigorously with the crop. Growers face a major challenge in field pea production due to the poor competitive ability of the crop. Canadian farmers spend more than $\$ 500$ million each year on herbicides to control weeds in their crops (Croplife Canada, 2003). Late flushes of weeds not controlled by herbicides in wheat, barley, and canola combine to total \$120 million in crop losses (O’Donovan et al., 2005). Pulse crops are the 
most susceptible crops to weed interference as typical yield losses of $20 \%$ to $40 \%$ are common (Wall et al., 1991). Yield losses as high as 80\% can be observed (Boreboom and Young 1995). This lack of competitive ability leads to reluctance from growers to include pulse crops in their crop rotation. Including competitive crop cultivars in crop rotations is an essential part of integrated weed management (Dew, 1972).

Developing more competitive field pea cultivars could help expand the acres seeded to field pea. Often, there is a variation in competitive ability between crop cultivars (Tepe et al., 2005; Willenborg et al., 2005; Watson et al., 2006). However, field pea may be an exception to this as breeding has mainly focused on improving lodging and disease resistance. As a result competitive ability may have been selected against in favor of improving the aforementioned agronomic traits. An example of this is semi-leafless field pea cultivars, which farmers prefer to grow; consequently, plant breeders have reacted by releasing cultivars that are almost leafless and show little variation in plant height (vine length) (Willenborg, 2011). Leaf area (Cote et al., 1992) and plant height (Wall et al., 1991; Harker et al., 2008) are key components of a competitive crop. McDonald (2003) and Wall and Townley-Smith (1996) have shown that tall field pea cultivars will yield higher than short and medium height cultivars under weed competition. Harker et al. (2008) have shown that unsprayed forage cultivars (leafy) of field pea can yield as much or more than semi-leafless cultivars that have received a herbicide application. Similar research has also found that leafy cultivars were more competitive with wild mustard (Sinapsis arvensis) than semi-leafless cultivars (Wall et al., 1991).

As a consequence of breeding to improve agronomic traits, we may have reached a point where competitive ability has been bred out of field peas or the variation for traits that confer competitive ability between cultivars is insignificant. Therefore, it is important to determine if differences in competitive ability exist between field pea cultivars and if so, which traits are driving these competitive differences.

\section{Materials and Methods}

A field experiment was conducted at five locations over two years to evaluate the ability of 14 semi-leafless field pea cultivars to withstand and suppress weed competition. Six yellow genotypes, six green genotypes, one dun genotype, and one semi-leafless forage genotype were chosen based on a variation in vine length and seed size. The experiment was conducted at the Kernen Research Farm near Saskatoon, Saskatchewan, at a research site near Floral, Saskatchewan, and the Ellerslie Research Farm site, near St. Albert, Alberta. The Kernen site was lost in 2012 due to excess moisture and therefore will not be discussed in further detail. All fourteen semi-leafless field pea cultivars and a plot containing no crop (control) were grown either with or without competition from pseudo weeds, which consisted of wheat (CDC Imagine) and canola (45H73). The wheat and canola varieties used in this study were tolerant to imidazolinone herbicides, which allowed for control of weeds but not the field peas or pseudo weeds. The experimental design was a four replicate split-block, with each treatment replicated four times. The main plots (half-block) either had pseudo weeds present or absent. The subplots 
consisted of the fourteen semi-leafless field pea cultivars and the no crop (control). The subplots were randomized within main plots, and main plots were randomized among replications.

Plots were established on barley stubble at all sites. All sites received a preseeding glyphosate burndown at $0.90 \mathrm{~kg}_{\text {ae }} \mathrm{ha}^{-1}$ just before or immediately after planting to control emerged weeds. Germination tests were taken prior to seeding to compensate for differences in germination among cultivars. Prior to planting, the field pea seed was treated with Carbathiin and Thiram seed treatment at a rate of $300 \mathrm{ml}$ per $100 \mathrm{~kg}$ of seed to control seed and soil borne diseases. Planting was completed in Alberta with a small plot cone seeder with atom jet openers with an inter row spacing of $20 \mathrm{~cm}$. Saskatchewan was sown using a cone seeder with disc openers with an inter row spacing of $22.5 \mathrm{~cm}$. the field peas were planted at a depth of $5 \mathrm{~cm}$ at both sites. The soil was inoculated with an appropriate granular Rhizobium inoculum at $4.6 \mathrm{~kg}$ $\mathrm{ha}^{-1}$. Monammonium Phosphate (11-52-0-0) was placed with the seed at planting at a rate of 21.5 $\mathrm{kg} \mathrm{ha}^{-1}$ fertilizer product. The pseudo weeds were planted immediately following the peas at a depth of $1.9 \mathrm{~cm}$ at both sites by cross seeding them over the main plots. The openers were run through the weed-free plots to simulate the same type of disturbance. Field pea was planted at a target density of 75 plants $\mathrm{m}^{-2}$, while the target for the pseudo weeds was $40-50$ plants $\mathrm{m}^{-2}$ range (20-25 plants $\mathrm{m}^{-2}$ each). Imazamox plus Imazethapyr was applied at a rate of $43 \mathrm{~g}$ ai ha $\mathrm{ha}^{-1}$ at the appropriate crop stage. Most of the weed community was eliminated except the wheat and canola. Any weeds in the weed-free plots not controlled by the in-crop herbicide application were removed by hand weeding. In 2012 the Floral, SK site received two fungicide applications of Chlorothalonil at $3000 \mathrm{ml}$ per hectare rate followed by Prothioconazole at $420 \mathrm{ml}$ per hectare rate and St. Albert received one fungicide application of Chlorothalonil at $3000 \mathrm{ml}$ per hectare rate at the appropriate crop stages. In 2013, less disease pressure was evident, leading to only one fungicide application at all three sites of Chlorothalonil at $3000 \mathrm{ml}$ per hectare rate. Insect pressure was also a concern, resulting in an application at Floral in 2012 of Lambda-Cyhalothrin at $83 \mathrm{ml}$ per hectare rate.

Vine length was measured from the soil surface to the top of the apical meristem on five random plants from each plot during flowering. Leaf area was measured during flowering in one $0.125 \mathrm{~m}^{-2}$ area from each plot by cutting off all of the stipules (leaves) and running them through a leaf area meter. Field pea and pseudo weed aboveground biomass was sampled and separated just prior to plant senescence from two $0.25 \mathrm{~m}^{-2}$ areas. Biomass samples were dried at $80^{\circ} \mathrm{C}$ for 72 hours and weighed. Plots were harvested with a small plot combine at Saskatchewan for all sites over the two years, while at Ellerslie, hand sickles were used to cut a $1.83 \mathrm{~m}$ by four rows area in each plot and were threshed in October. In July 2012, Ellerslie was subjected to flooding in areas and hail damage in August. Consequently, a $0.25 \mathrm{~m}^{-2}$ from each plot was vacuumed and weighed to account for the harvest losses. The seed was dried to a constant moisture, weighed, cleaned with a dockage tested a weighed for true pea and pseudo weed yield. 


\section{Results and Discussion}

Field pea biomass, field pea yield, the correlations between traits that may confer competitive ability, and AWC and AC were analyzed with the sites combined within each province, so the data presented as Alberta is from the two Alberta site-years and Saskatchewan is from the three site-years in Saskatchewan. Field pea biomass was not significantly different among cultivars, but was significantly different among the presence or absence of weeds, known from here on as treatment. The interaction among the cultivars and treatments was not significant at Alberta ( $p=0.3305),(p=<0.0001)$, and $(p=0.5868)$, but was significant at Saskatchewan ( $p$ $=<0.0001)$ and $(\mathrm{p}=<0.0001)$, but the cultivar by treatment interaction was not significant at Saskatchewan $(\mathrm{p}=0.6288)$. Due to the lack of a significant interaction, the treatments do not need to be separated and as we would expect a difference in field pea biomass among the weedy and weed-free treatments as weed competition will reduce field pea biomass, this will not be discussed as the differences between the cultivars for biomass production is of much importance.

At Saskatchewan sites, CDC Dakota and CDC Striker produced significantly more biomass than the cultivars that produced the least biomass (Figure 1). CDC Dakota and CDC Striker produced 48\% and 37\% more biomass than Reward, which produced the least biomass (4814.05 $\mathrm{kg} \mathrm{ha}^{-1}$ ). When an average biomass of the four cultivars (Cutlass, Stratus, CDC Leroy, and Reward) that produced the least biomass was taken, the average of CDC Dakota and CDC Striker produced 34\% more biomass. CDC Dakota and CDC Striker were only significantly different from CDC Patrick, CDC Mozart, Camry, Cooper, Cutlass, CDC Leroy, Stratus, and Reward Stratus; all other cultivars were intermediate to these. This may suggest that CDC Dakota and CDC Striker are able to produce the most biomass whether under the presence or absence of weed competition, which indicates that the genotypes were not responding differently to the presence of weed competition. 


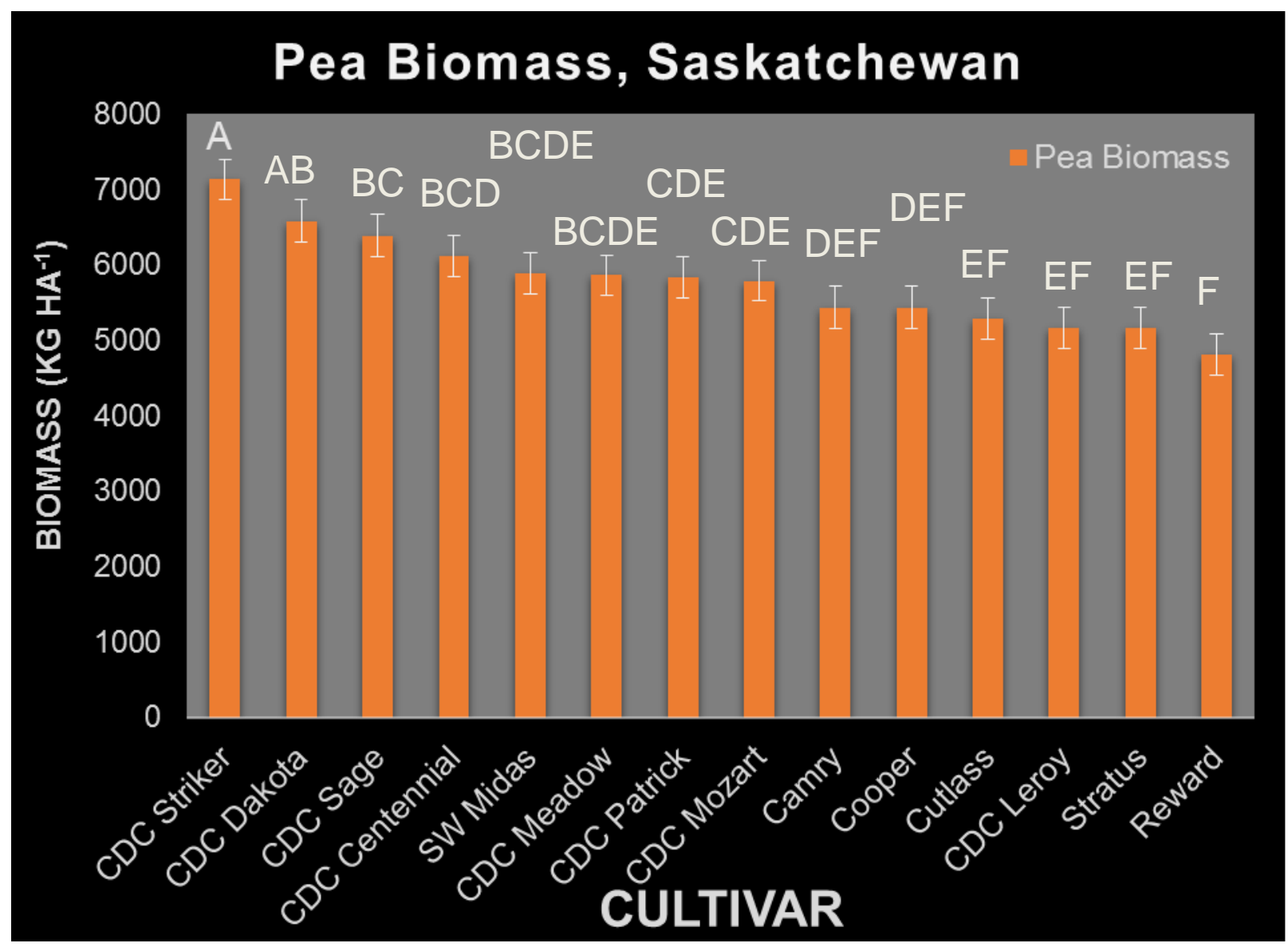

Figure 1. Field pea biomass, Saskatchewan. Error bars represent standard error of means. Means with the same letters are not significantly different.

Field pea yield was not significant at Alberta among cultivars $(p=0.0854)$ and neither was the cultivar by treatment interaction $(p=0.5394)$. There were, however, significant differences between the weedy and weed-free treatments $(p=0.0007)$. Differences among the competition treatments was expected and is not surprising as the field pea genotypes will yield less under weed competition.

At Saskatchewan, pea yield was significantly affected by cultivars $(\mathrm{p}=<0.0001)$ and competition treatments $(p=0.0015)$, but their interaction was not significant $(p=0.3000)$. CDC Dakota produced the greatest field pea yield (4555.85 $\mathrm{kg} \mathrm{ha}^{-1}$ ) and Reward produced the lowest field pea yield (3023.20 kg ha ${ }^{-1}$ ) (Figure 2). CDC Dakota yielded 51\% higher than Reward. The four lowest yielding field pea cultivars were CDC Mozart, Camry, Stratus, and Reward, when an average is taken of their yield, CDC Dakota produced 35\% more field pea yield than the four lowest yielding field pea cultivars. This may indicate that cultivars such as CDC Dakota, CDC Patrick, CDC Meadow, and CDC Leroy are able to produce greater yields regardless of weed competition. 


\section{Pea Yield, Saskatchewan}

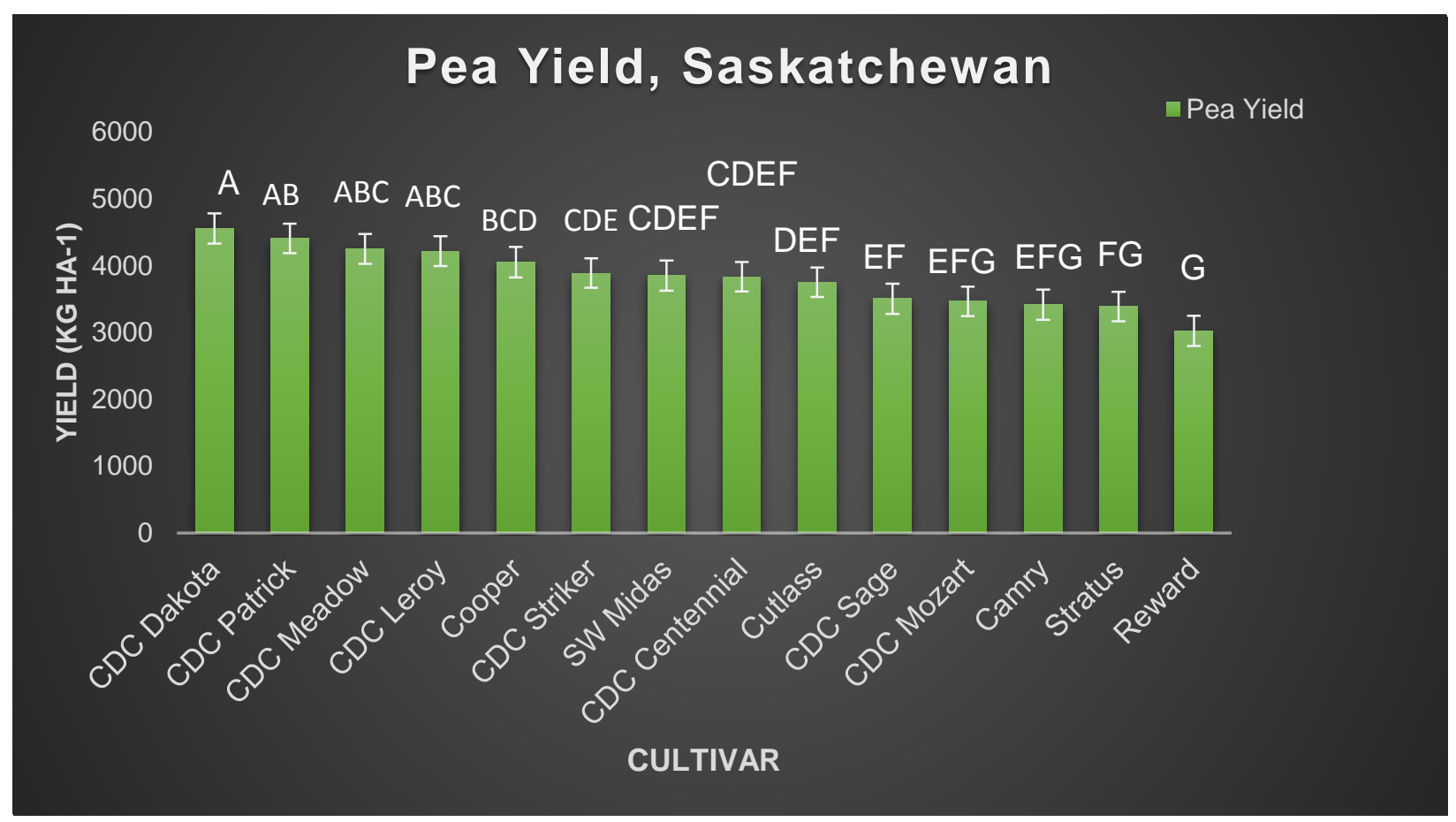

Figure 2. Field pea yield, Saskatchewan, SK. Error bars represent standard error of means. Means with the same letters are not significantly different.

Correlations among traits that may be driving the competitive ability of semi-leafless field pea cultivars is shown below in Tables 1 and 2. At Saskatchewan, there are significant correlations, but no traits strongly correlated with each other (Table 1). Weed seed production and weed biomass is the only highly significant and strong correlation (0.77995), which was expected. Leaf area index does correlate with field pea height $(0.40843)$, field pea biomass (0.31815) and field pea yield (0.40451), but these correlations are weak to intermediate at best. Similar results were observed in the correlations at the Alberta sites (Table 2). Only leaf area index only correlated positively with field pea yield (0.15576), but this relationship was not significant.. The results from both Saskatchewan and Alberta show that no traits showed a strong correlation, and thus none of the above-ground traits measured in this study are driving competitiveness in semi-leafless field pea cultivars. 
Table 1. Correlations in the three combined site-years in Saskatchewan. ${ }^{*}, * *, * * *$, significant at the $0.05,0.01$, and 0.001 probability levels.

\begin{tabular}{|c|c|c|c|c|c|c|c|c|}
\hline & $\begin{array}{l}\text { Leaf area } \\
\text { index }\end{array}$ & Pea height & $\begin{array}{l}\text { Pea } \\
\text { biomass }\end{array}$ & $\begin{array}{l}\text { Weed } \\
\text { biomass }\end{array}$ & Pea yield & Tkw & $\begin{array}{l}\text { Weed seed } \\
\text { production }\end{array}$ & $\begin{array}{l}\text { Days to } \\
\text { full } \\
\text { canopy } \\
\text { closure }\end{array}$ \\
\hline $\begin{array}{l}\text { Leaf area } \\
\text { index }\end{array}$ & 1.00000 & & & & & & & \\
\hline Pea height & $0.40843^{* * *}$ & 1.00000 & & & & & & \\
\hline $\begin{array}{l}\text { Pea } \\
\text { biomass }\end{array}$ & $0.31815^{\star * *}$ & $0.20488^{\star *}$ & 1.00000 & & & & & \\
\hline $\begin{array}{l}\text { Weed } \\
\text { biomass }\end{array}$ & $-0.35487^{\star \star \star}$ & $-0.37404^{\star \star \star \star}$ & $-0.37777^{\star \star \star}$ & 1.00000 & & & & \\
\hline Pea yield & $0.40451^{\star \star \star}$ & $0.34195^{\star \star \star}$ & $0.41410^{\star \star \star}$ & $-0.50069^{\star \star \star}$ & 1.00000 & & & \\
\hline Tkw & $-0.17919^{\star \star \star}$ & $-0.59093^{\star \star \star}$ & -0.10255 & $0.28339^{\star \star}$ & $-0.12718^{*}$ & 1.00000 & & \\
\hline $\begin{array}{l}\text { Weed seed } \\
\text { production }\end{array}$ & $-0.32530^{\star * *}$ & $-0.47311^{\star * *}$ & $-0.51628^{\star \star \star}$ & $0.77995^{\star \star \star}$ & $-0.50578^{\star * *}$ & $0.44945^{\star \star *}$ & 1.00000 & \\
\hline $\begin{array}{l}\text { Days to full } \\
\text { canopy } \\
\text { closure }\end{array}$ & -0.10180 & -0.03916 & 0.02747 & $-0.22662^{\star *}$ & $-0.14957^{\star *}$ & $-0.17051^{* *}$ & $-0.26869^{* *}$ & 1.00000 \\
\hline
\end{tabular}

Table 2. Correlations in the two combined site-years in Alberta. *,**,***, significant at the $0.05,0.01$, and 0.001 probability levels.

\begin{tabular}{|c|c|c|c|c|c|c|c|}
\hline & $\begin{array}{l}\text { Leaf area } \\
\text { index }\end{array}$ & Pea height & Pea biomass & $\begin{array}{l}\text { Weed } \\
\text { biomass }\end{array}$ & Pea yield & $\begin{array}{l}\text { Weed seed } \\
\text { production }\end{array}$ & Tkw \\
\hline $\begin{array}{l}\text { Leaf area } \\
\text { index }\end{array}$ & 1.00000 & & & & & & \\
\hline Pea height & 0.05559 & 1.00000 & & & & & \\
\hline $\begin{array}{l}\text { Pea } \\
\text { biomass }\end{array}$ & 0.03549 & $-0.31672^{* * *}$ & 1.00000 & & & & \\
\hline $\begin{array}{l}\text { Weed } \\
\text { biomass }\end{array}$ & 0.01597 & $0.52437^{* * *}$ & $-0.75999 * * *$ & 1.00000 & & & \\
\hline Pea yield & $0.15576 *$ & $-0.08280 * * *$ & $0.53605^{* * *}$ & $-0.53511^{* * *}$ & 1.0000 & & \\
\hline $\begin{array}{l}\text { Weed seed } \\
\text { production }\end{array}$ & 0.11411 & $0.29111^{* *}$ & $-0.56765 * * *$ & $0.59895 * * *$ & $-0.45861^{* * *}$ & 1.00000 & \\
\hline Tkw & -0.08791 & -0.04711 & -0.10191 & 0.18487 & $0.21777^{* * *}$ & $-0.45861^{* * *}$ & 1.00000 \\
\hline
\end{tabular}

Ability to withstand competition (AWC) and ability to compete (AC) are shown in Tables 3 and 4 for Saskatchewan and Alberta. These tables display cultivar rankings based on percent yield loss and percent dockage. AWC was calculated as 100 multiplied by the yield of the weedy plots divided by the yield of the weedy-free plots; it can also be calculated as 100 
subtract percent yield loss. AC calculation was based on dockage (percent dockage of pseudo weed seed in each sample). AC is calculated 100 - \%dockage (Watson et al., 2006).

At Saskatchewan, CDC Centennial and CDC Mozart were significantly better in their ability to withstand competition than Reward. However, the remaining cultivars are intermediate to these three. With regard to AC, CDC Dakota. CDC Patrick, and CDC Meadow withstood competition from weeds significantly better than Reward. As well, cultivars do differ in their rank between the two calculations, CDC Centennial and CDC Mozart are the best cultivars pertaining to their AWC but change their rank to intermediary for AC. CDC Dakota, CDC Patrick, and CDC Meadow follow similarly. Other cultivars such as, CDC Patrick were more consistent, performing well in both AWC and AC, whereas Reward was consistently the worst.

At Alberta, there were no statistically significant differences between the cultivars in their AWC. However, on a biological level, reducing yield loss from 39\% to 9\% could be very significant from a grower's standpoint. Significant differences were noted for AC between CDC Striker, CDC Dakota, and CDC Sage. All of these cultivars were significantly better at competing than Cooper and Stratus. CDC Striker, CDC Sage, and CDC Meadow appear to perform well for AWC and AC, whereas Reward was again consistently poor across both categories. These results show that the different traits and combinations of traits that each of the cultivars possess are important in their ability to withstand competition or to reduce pseudo weed seed production.

Table 3. Ability of semi-leafless field pea cultivars to Withstand Competition and Ability to Compete, three combined site-years in Saskatchewan.

\begin{tabular}{|c|c|c|c|c|c|}
\hline \multicolumn{6}{|c|}{ SK, AWC and AC } \\
\hline \multicolumn{3}{|c|}{$\begin{array}{l}\text { Ability to Withstand Competition } \\
\text { (100(yield weedy plots / yield weed-free plots)) } \\
\text { P-value } 0.0089\end{array}$} & \multicolumn{3}{|c|}{$\begin{array}{l}\text { Ability to Compete } \\
\text { (100-\%dockage) } \\
\text { P-value } 0.0092\end{array}$} \\
\hline Rank & Cultivar & AWC & Rank & Cultivar & $A C$ \\
\hline 1 & CDC Centennial & $91 \mathrm{a}$ & 1 & CDC Dakota & $86 a$ \\
\hline 2 & CDC Mozart & $88 a$ & 2 & CDC Patrick & $83 a$ \\
\hline 3 & CDC Patrick & $81 \mathrm{ab}$ & 3 & CDC Meadow & $83 a$ \\
\hline 4 & CDC Sage & $78 a b$ & 4 & Cooper & $82 \mathrm{ab}$ \\
\hline 5 & CDC Striker & $76 a b$ & 5 & CDC Centennial & $81 \mathrm{ab}$ \\
\hline 6 & Cutlass & $75 a b$ & 6 & CDC Striker & $81 \mathrm{ab}$ \\
\hline 7 & CDC Dakota & $73 a b$ & 7 & CDC Leroy & $81 \mathrm{ab}$ \\
\hline 8 & CDC Meadow & $72 a b$ & 8 & Cutlass & $80 \mathrm{ab}$ \\
\hline 9 & CDC Leroy & $71 a b$ & 9 & CDC Sage & $79 a b$ \\
\hline 10 & Cooper & $71 \mathrm{ab}$ & 10 & CDC Mozart & $78 \mathrm{ab}$ \\
\hline 11 & Stratus & $71 \mathrm{ab}$ & 11 & SW Midas & $77 \mathrm{ab}$ \\
\hline 12 & Camry & $69 a b$ & 12 & Camry & $75 \mathrm{ab}$ \\
\hline 13 & SW Midas & $69 a b$ & 13 & Stratus & $73 \mathrm{ab}$ \\
\hline 14 & Reward & $61 \mathrm{~b}$ & 14 & Reward & $69 \mathrm{~b}$ \\
\hline
\end{tabular}


Table 4. Ability of semi-leafless field pea cultivars to Withstand Competition and Ability to Compete, two combined site-years in Alberta.

\begin{tabular}{|c|c|c|c|c|c|}
\hline \multicolumn{6}{|c|}{$\mathrm{AB}, \mathrm{AWC}$ and $\mathrm{AC}$} \\
\hline \multicolumn{3}{|c|}{$\begin{array}{c}\text { Ability to Withstand Competition } \\
\text { (100(yield weedy plots / yield weed-free plots)) } \\
\text { P-value } 0.8095\end{array}$} & \multicolumn{3}{|c|}{$\begin{array}{l}\text { Ability to Compete }(100-\% \text { dockage }) \\
\text { P-value }<0.0001\end{array}$} \\
\hline Rank & Variety & AWC & Rank & Variety & $\mathrm{AC}$ \\
\hline 1 & CDC Sage & $96 a$ & 1 & CDC Striker & 98 a \\
\hline 2 & CDC Striker & $95 a$ & 2 & CDC Dakota & $97 \mathrm{ab}$ \\
\hline 3 & Stratus & $83 a$ & 3 & CDC Sage & $97 \mathrm{abc}$ \\
\hline 4 & CDC Meadow & 80 a & 4 & CDC Meadow & 96 abcd \\
\hline 5 & CDC Centennial & $75 a$ & 5 & CDC Mozart & $96 \mathrm{abcd}$ \\
\hline 6 & CDC Dakota & $72 \mathrm{a}$ & 6 & CDC Patrick & $95 \mathrm{abcd}$ \\
\hline 7 & CDC Patrick & $66 a$ & 7 & CDC Leroy & $95 \mathrm{abcd}$ \\
\hline 8 & CDC Leroy & $66 a$ & 8 & SW Midas & $95 \mathrm{abcd}$ \\
\hline 9 & Cooper & $64 a$ & 9 & CDC Centennial & $94 \mathrm{abcd}$ \\
\hline 10 & SW Midas & $63 a$ & 10 & Cutlass & $94 \mathrm{abcd}$ \\
\hline 11 & Camry & $63 a$ & 11 & Reward & $93 \mathrm{bcd}$ \\
\hline 12 & Cutlass & $63 a$ & 12 & Camry & $93 \mathrm{~cd}$ \\
\hline 13 & Reward & $57 a$ & 13 & Cooper & $92 d$ \\
\hline 14 & CDC Mozart & $57 a$ & 14 & Stratus & $92 \mathrm{~d}$ \\
\hline
\end{tabular}

\section{Conclusions}

There were significant correlations at both Saskatchewan and Alberta, but none were strong enough to explain why the observed differences in competitive ability. Field pea cultivars did have different abilities to withstand competition and to compete despite the lack of correlations between traits observed in this study. CDC Dakota consistently produced higher biomass and higher seed yields than many of the other cultivars and seems to possess traits that help it to compete with the pseudo weeds. Though, differences did exist among these cultivars to compete with and to withstand competition from weeds, the weak correlations we observed suggest that none of the traits measured in this study is key to driving competitive ability in field pea.

\section{References}

Boreboom, C.M. and Young, F.L. 1995. Effect of postplant tillage and crop density on broadleaf weed control in dry pea and lentil. Weed Technol. 9:99-106.

Canola Council of Canada. 2012. Chapter 3 - Canola growth stages, Growth stages of the canola plant. Accessed from: http://www.canolacouncil.org/chapter3.aspx

Canola Council of Canada. 2012. Chapter 4 - Effects of moisture, Crop water use comparisons Accessed from: http://www.canolacouncil.org/chapter4.aspx 
Cote, R., Gerrath, M., Poslusznyu, and Grodzinski, B. 1992. Comparative leaf development of conventional and semi-leafless peas (Pisum sativum). Can. J. Bot. 70: 571-580.

CropLife Canada. 2003. Herbicide sales. CropLife Canada, Ottawa, ON.

Dew, D.A. 1972. An Index of competition for estimating crop loss due to weed competition. J. Agron. Crop Sci. 188:176-184.

Harker, K.N., G.W. Clayton, and Blackshaw, R.E. 2008. Comparison of leafy and semi-leafless pea for integrated weed management. Weed Technol. 22:124-131.

McDonald, G. K. 2003. Competitiveness against grass weeds in field pea genotypes. Weed Res. 43:48-58.

O’Donovan, J. T., Thomas, A. G., Leeson, J. Y. and Maurice, D. C. 2005. The impact of residual weeds on field crops in western Canada: moving beyond subjective estimates. Weed Sci. Soc. Am. Abstr. 45:29.

Saskatchewan Ministry of Agriculture. 2011. 2010 Specialty crop report. Accessed from: http://www.agriculture.gov.sk.ca/Default.aspx?DN=71bbc952-b3fe-4601-9ece-a666fc87b425.

Saskatchewan Pulse Growers. 2009. Overview of pulses. Accessed from: http://www.saskpulse.com/producer/industry/index.php

Tepe, I., Erman, E., Yazlik, A., Levent, R., and Ipek, K. 2005, Comparison of some winter lentil cultivars in crop-weed protection. Crop Prot. 24:585-589.

Wall, D.A., Friesen, G.H., and Bhati, T.K. 1991. Wild mustard interference in traditional and semi-leafless field pea. Can. J. Plant Sci. 71:473-480.

Wall, D. A. and Townley-Smith, L. 1996. Wild Mustard (Sinapsis arvensis) responses to field pea (Pisum sativum) cultivar and seeding rate. Can. J. Plant Sci. 76:907-914.

Watson, P.R., Derksen, D.A., and Van Acker, R.C. 2006. Ability of 29 barley cultivars to compete and withstand competition. Weed Sci. 54: 783-792.

Willenborg, C.J., Rossnagel, B.N., and Shirtliffe, S.J. 2005. Oat caryopsis size and genotype effects on wild oat - oat competition. Crop Sci. 45: 1410-1416. 